\title{
HUBUNGAN PEMBERIAN MAKANAN PENDAMPING ASI DENGAN STATUS GIZI BAYI USIA 6-24 BULAN
}

\section{Gesit Kusuma Wardani}

Mahasiswa Pascasarjana Ilmu Kesehatan Masyarakat Universitas Sebelas Maret Indonesia

\section{Corresponding author: \\ Gesit Kusuma Wardani}

Mahasiswa Pascasarjana Ilmu Kesehatan Masyarakat Universitas Sebelas Maret Indonesia

Email: gesitkusuma92@gmail.com

\section{Article Info:}

Dikirim: 7 September 2018

Ditinjau: 8 September 2018

Diterima: 13 September 2018

DOI:

https://doi.org/10.33475/jikmh.v7i2.22

\section{Abstract}

Transitional period (6 - 12 months) is a process of the commencement of special food administration in addition to breast milk. The complementary food varies and contains energy substances (carbohydrates and fats), builder substances (proteins), and regulating substances (vitamins and minerals) as required. The period will be well materialized if during this period the babies get appropriate nutrition intake for optimal development and growth.The study aimed to investigate correlation between the administration of complementary food and the nutritional status of babies aged 6-24 months in Setabelan Ward, Surakarta City. This research used the analytical observational method with the cross-sectional design. The samples of research were taken by using the accidental sampling technique. The subjects of research were 40 mothers who had babies aged 6-24 months in the ward aforementioned. The data of research were collected through 24-hour food recall scale and anthropometric index of body weight/age. They were statistically analyzed by using the contingency coefficient. In the group giving appropriate complementary food, $77.3 \%$ of babies had a good nutritional status, and $22.7 \%$ had a less good nutritional status. Conversely, in the group giving inappropriate complementary food $77.8 \%$ had a less good nutrition status and $22.2 \%$ had a good nutritional status. The result of statistical test shows that the p-value was 0.001 and the value of closeness of correlation between the two variables was 0.481. There was a moderate correlation between the administration of complementary food and the nutritional status of babies aged 6-24 months in Setabelan Ward, Surakarta City.

Keywords: Transition periode, Administration of complementary food, Nutritional status Babies

\begin{abstract}
Abstrak
Periode peralihan (6 - 12 bulan) merupakan suatu proses dimulainya pemberian makanan khusus selain ASI yang beraneka ragam dan mengandung zat tenaga (karbohidrat dan lemak), zat pembangun (protein), dan zat pengatur (vitamin dan mineral) sesuai dengan kebutuhan tubuhnya. Periode tersebut dapat terwujudkan apabila pada masa ini bayi dan anak memperoleh asupan gizi yang sesuai untuk tumbuh kembang optimal. Penelitian ini bertujuan untuk mengetahui adanya hubungan antara pemberian makanan pendamping ASI dan status gizi bayi usia 6-24 bulan di Kelurahan Setabelan Kota Surakarta. Penelitian ini menggunakan jenis penelitian analitik korelasi, dengan desain penelitian cross sectional dan teknik sampling accidental sampling. Subjek penelitian 40 ibu yang memiliki bayi 6-24 bulan di Kelurahan Setabelan kota Surakarta. Alat ukur yang digunakan food recall 24 jam dan antropometri indeks BB/U dengan uji statistik koefesien kontingensi. Penelitian ini menyebutkan pada kelompok responden yang memberikan makanan pendamping ASI yang tepat diperoleh status gizi baik 77,3\% dan status gizi kurang $22,7 \%$. Sedangkan kelompok responden yang memberikan makanan pendamping ASI tidak tepat memiliki status gizi kurang $77,8 \%$ dan status gizi baik $22,2 \%$. Hasil uji statistik didapatkan bahwa $p=0,001$ dan keeratan hubungan 0,481. Hal ini membuktikan bahwa ada hubungan antara pemberian MP ASI dengan status gizi bayi usia 6-24 bulan di Kelurahan Setabelan Kota Surakarta dengan keeratan hubungan sedang.
\end{abstract}

Kata Kunci: Masa Peralihan, Pemberian MP ASI, Status Gizi Bayi 


\section{PENDAHULUAN}

Status gizi menjadi indikator dalam menentukan derajat kesehatan anak. Gizi pada masa anak sangat berpengaruh terhadap tumbuh kembangnya bahkan sejak masih dalam kandungan sekalipun, gizi memegang peran yang penting (Soetjiningsih, 2010). Sebaliknya apabila bayi dan anak pada masa ini tidak memperoleh makanan sesuai kebutuhan gizinya, maka periode emas akan berubah menjadi periode kritis yang akan mengganggu tumbuh kembang bayi dan anak, baik pada masa ini maupun masa selanjutnya (Nasar, 2011).

Masa peralihan (6 - 12 bulan) merupakan masa rawan pertumbuhan anak karena pada masa inilah rawan terjadinya malnutrisi yang berlanjut dan berkontribusi pada tingginya prevalensi malnutrisi. Praktik pemberian makan yang benar pada bayi dan balita bisa berperan dalam menurunkan angka kematian balita. Sebagian besar penyebab kematian balita ada kaitannya dengan gizi kurang atau gizi buruk akibat praktik pemberian makan yang tidak benar pada masa bayi, misalnya pemberian makanan pendamping ASI yang terlalu dini atau terlambat serta makanan pendamping ASI yang tidak memenuhi kebutuhan zat gizi secara kualitas maupun kuantitas dan tidak higienis (Buletininfo, 2012). Upaya meminimalisir masalah tersebut, WHO/UNICEF merekomendasikan bahwa bayi usia 6-24 bulan diberikan makanan pendamping ASI dengan memperhatikan waktu yang tepat (setelah usia 6 bulan), memenuhi prinsip gizi seimbang dan memadai baik itu protein, karbohidrat, vitamin, mineral maupun lemak dan menjamin keamanannya karena pada usia ini anak berada pada periode pertumbuhan dan perkembangan cepat, mulai terpapar terhadap infeksi dan secara fisik mulai aktif, sehingga kebutuhan terhadap zat gizi harus terpenuhi dengan memperhitungkan aktivitas bayi/anak dan keadaan infeksi (Debi, 2013).
Berdasarkan Kementerian Kesehatan RI Direktorat Jenderal Bina Gizi Dan Kesehatan Ibu Dan Anak Direktorat Bina Gizi 2012, jumlah kasus balita gizi buruk yang dilaporkan dari tahun 2009 jumlah kasus balita gizi buruk meningkat dibandingkan tahun 2008 yaitu dari 41.064 kasus menjadi 56.941 kasus sedangkan pada tahun 2010 dan 2011 jumlah kasus gizi buruk yang dilaporkan kembali turun menjadi 43.616 kasus dan 40.412 kasus. Laporan terakhir didapatkan pada tahun 2013 meningkat kembali menjadi 40.549 kasus. Jumlah kasus gizi buruk yang ditemukan dan ditangani di Provinsi Jawa Tengah 1.597 kasus. Khususnya untuk Kota Surakarta pada tahun 2012 insiden gizi kurang terdapat 1293 kasus, dimana kejadian terbanyak terdapat di Puskesmas Setabelan yaitu $8,26 \%$.

Berdasarkan studi pendahuluan wawancara yang dilakukan pada tanggal 19 Desember 2014, data pemberian makanan pendamping ASI berdasarkan informasi dari kader dijumpai masih banyak ibu balita yang hanya memberikan makanan berupa bubur beras saja tanpa dilengkapi dengan bahan makanan lain yang bergizi, seperti lauk hewani dan sayuran. Masih terdapat pula ibu balita yang memberikan makanan kepada bayinya hanya berupa kuah sayur-sayuran tanpa bahan makanan sumber protein. Di samping itu, ditemui pula adanya pendapat masyarakat bahwa MPASI padat gizi hanya dapat dibuat dari bahan makanan sumber hewani, yang harganya relatif mahal. Sedangkan data status gizi diperoleh data tahun 2014 terdapat gizi kurang sebanyak 28 kasus dari 768 balita. Penelitian ini bertujuan untuk mengetahui adanya hubungan antara pemberian makanan pendamping ASI dan status gizi bayi usia 6-24 bulan di Kelurahan Setabelan Kota Surakarta. 


\section{METODE}

Penelitian ini merupakan penelitian analitik observasional dengan desain penelitian cross sectional. Bertujuan untuk mengetahui hubungan pemberian makanan pendamping ASI dengan Status Gizi bayi usia 6-24 Bulan di Kelurahan Setabelan Kota Surakarta Tahun 2015". Populasi dalam penelitian ini adalah semua bayi usia 6-24 bulan di Kelurahan Setabelan tahun 2015 sebanyak 46 responden sedangkan jumlah sampel sebesar 40 responden dengan teknik pengambilan accidental sampling. Pada penelitian ini, peneliti menggunakan alat ukur formulir food recall 24 jam untuk mengukur pemberian Makanan Pendamping ASI. Food recall dilakukan dengan mencatat jenis dan jumlah bahan makanan yang dikonsumsi pada periode 24 jam yang lalu. Dalam metode ini responden menceritakan semua yang dimakan dan diminum selama 24 jam yang lalu (kemarin) kemudian peneliti melakukan konversi dari URT ke dalam ukuran berat (gram) dan menganalisis bahan makanan ke dalam zat gizi dengan menggunakan Daftar Komposisi Bahan Makanan (DKBM) /aplikasi NutriSurvey 2007, selanjutnya membandingkan dengan Angka Kecukupan Gizi (AKG) untuk Indonesia.

Status gizi diukur dengan antropometri indeks BB/U menurut WHO-NCHS. Berat badan diukur dengan timbangan digital dengan kapasitas $150 \mathrm{~kg}$ dan ketelitian 50 gram, menggunakan baterai alkaline 3A sebanyak 2 buah. Pada penelitian ini teknik pengumpulan data dengan metode wawancara dan observasi. Waktu pengumpulan data dilakukan pada bulan Mei 2015 dengan cara mendatangi responden (door to door).

\section{HASIL DAN PEMBAHASAN}

Karakteristik responden berdasarkan waktu pemberian makanan pendamping ASI diperoleh bahwa sebagian besar bayi diberi MPASI saat usia 6 bulan $(60 \%)$, sedangkan bayi yang diberi MPASI kurang atau lebih dari 6 bulan mencapai $40 \%$. Karakteristik responden berdasarkan pemberian MPASI sesuai prinsip gizi seimbang didapatkan data bahwa hampir semua ibu di kelurahan Setabelan sudah memberikan makanan pendamping ASI sesuai prinsip gizi seimbang (95\%). Karakteristik responden berdasarkan keamanan Pemberian Makanan Pendamping ASI diperoleh bahwa dalam memberikan makanan pendamping ASI semua ibu di kelurahan Setabelan (100\%) sudah melakukan cuci tangan dan mencusi peralatan terlebih dahulu. Distribusi frekuensi pemberian makanan pendamping ASI didapatkan data yaitu dapat diketahui bahwa dari 40 responden, sebagian besar pemberian MP ASI dalam kategori tepat yaitu sebanyak 22 responden $(55,0 \%)$ sedangkan yang masuk dalam kategori tidak tepat sejumlah 18 responden $(45,0 \%)$.

Tabel 1.1 Distribusi frekuensi status gizi bayi 6-24 bulan

\begin{tabular}{|l|c|c|}
\hline Kategori & Frekuensi & Persentase \\
\hline Gizi lebih & 0 & 0 \\
\hline Gizi baik & 21 & 52,5 \\
\hline Gizi kurang & 19 & 47,5 \\
\hline Total & 40 & 100 \\
\hline
\end{tabular}

Dari tabel 1.1 tentang distribusi frekuensi status gizi bayi usia 6-12 bulan menunjukkan bahwa status gizi bayi usia 6-24 bulan di wilayah Kelurahan Setabelan Kota Surakarta didominasi oleh status gizi baik mencapai $52,5 \%$. 
Tabel 1.2 Cross Tabulasi Pemberian ASI Eksklusif dengan Status Gizi Bayi Usia 6-12 Bulan

\begin{tabular}{|l|c|c|c|c|c|c|}
\hline \multirow{2}{*}{$\begin{array}{l}\text { Pemberian } \\
\text { Makanan }\end{array} \begin{array}{l}\text { Pendamping } \\
\text { ASI }\end{array}$} & \multicolumn{2}{|c|}{$\begin{array}{c}\text { Gizi } \\
\text { Lebih }\end{array}$} & \multicolumn{2}{|c|}{ Gizi Baik } & \multicolumn{2}{c|}{ Gizi Kurang } \\
\cline { 2 - 7 } & $\mathrm{F}$ & $\%$ & $\mathrm{~F}$ & $\%$ & $\mathrm{~F}$ & $\%$ \\
\hline MPASI tepat & 0 & 0 & 17 & 77,3 & 5 & 22,7 \\
\hline $\begin{array}{l}\text { MPASI } \\
\text { tidak tepat }\end{array}$ & 0 & 0 & 4 & 22,2 & 14 & 77,8 \\
\hline
\end{tabular}

Berdasarkan hasil uji statistik yang menggunakan uji chi square dengan menggunakan SPSS 17.0 diperoleh hasil p sebesar 0,001. Apabila p lebih kecil dari $\alpha 0,05$ maka ada korelasi yang signifikan (Ha diterima). Hal ini menunjukan bahwa ada hubungan antara pemberian makanan pendamping ASI dengan status gizi bayi usia 6-24 bulan di wilayah Kelurahan Setabelan Kota Surakarta. Dari hasil uji statistik juga didapatkan nilai Contingency Coefficient sebesar 0,481 atau 48,1 persen yang menunjukkan bahwa sumbangan variabel pemberian MP-ASI terhadap variabel status gizi sebesar 48,1 persen, sedangkan sisanya $(100 \%-48,1 \%=51,9 \%)$ disumbangkan oleh faktor lain. Dengan kata lain kekuatan hubungan antara pemberian makanan pendamping ASI dengan status gizi bayi usia 6-24 bulan yaitu sedang 0,481 (Sedang : 0,40-0,599).

Pemberian makanan pendamping ASI mempunyai fungsi sebagai asupan tambahan bagi anak selain ASI. Hasil analisis bivariat menunjukan bahwa nilai $p$ value $=0,001 \quad(\mathrm{p}<0,05)$. Pada analisis ini, pemberian makanan pendamping ASI mempunyai hubungan dengan status gizi bayi 6-24 bulan. Sedangkan kekuatan hubungan antara pemberian makanan pendamping ASI dengan status gizi bayi usia 6-24 bulan yaitu sedang 0,481 (Sedang : 0,40-0,599). Hubungan yang sedang menandakan bahwa pemberian MP-ASI tidak dapat menjadi faktor penyebab utama terhadap status gizi bayi.

Masalah gizi penyebabnya adalah multifaktor, antara lain konsumsi makanan, penyakit infeksi, ketahanan pangan di kelurga, pola pengasuhan anak, pelayanan kesehatan dan lingkungan, tingkat pendidikan, dan tingkat sosial ekonomi masyarakat.

Studi-studi tentang status gizi menunjukkan adanya hubungan antara pemberian makanan pendamping ASI dengan status gizi bayi. Hal ini sejalan dengan penelitian yang dilakukan oleh Septiana (2010) tentang pola pemberian makanan pendamping ASI dan status gizi balita usia 6-24 bulan. Penelitian ini menujukkan adanya hubungan yang bermakna antara pola pemberian MPASI dan status gizi balita 6-24 bulan di Puskesmas Gedongtengen Yogyakarta. Selain itu diperkuat juga oleh penelitian yang dilakukan oleh Ratna (2010) yang menunjukkan adanya hubungan yang kuat antara pola pemberian MPASI dengan status gizi bayi usia 6-12 bulan di Desa Kaliori Kabupaten Banyumas tahun 2010.

Konsumsi makanan berpengaruh terhadap status gizi seseorang. Kondisi status gizi baik dapat dicapai bila tubuh memperoleh cukup zat gizi yang akan digunakan secara efesien, sehingga memungkinkan terjadinya pertumbuhan fisik, perkembangan otak, kemampuan kerja untuk mencapai tingkat kesehatan optimal. Hal ini sesuai dengan penelitian Eka (2012) di Kecamatan Tanralili Kabupaten Maros Makasar yang menyatakan ada hubungan pemberian makanan pendamping ASI dengan status gizi bayi usia 6-12 bulan dengan nilai chi-square 0,001 .

Berdasarkan hasil penelitian menunjukkan bahwa bayi yang diberi MP-ASI yang tepat $(55,0 \%)$ memiliki status gizi baik (77,3\%). Pemberian makanan pendamping ASI berkaitan langsung dengan asupan atau konsumsi anak. Sedangkan asupan makan 
merupakan faktor langsung yang mempengaruhi status gizi. Hal ini sejalan dengan teori yang dikemukakan oleh Ariani (2008), menyatakan bahwa makanan pendamping ASI mengandung gizi yang

diberikan kepada bayi/anak untuk memenuhi kebutuhan gizinya. Pemberian makanan pendamping ASI adalah untuk menambah energi dan zat-zat gizi yang diperlukan bayi karena ASI tidak dapat memenuhi kebutuhan bayi secara terus-menerus (sebagai komplemen dengan ASI

agar anak memperoleh cukup energi, protein dan zatzat gizi lainnya). Hayati (2009) mengungkapkan bahwa peranan makanan pendamping ASI sama sekali bukan untuk menggantikan ASI melainkan hanya untuk melengkapi ASI.

Data tabulasi silang pemberian makanan pendamping ASI dan status gizi bayi diketahui bahwa bayi usia 624 bulan yang mendapat makanan pendamping ASI yang tepat ternyata masih ada 5 bayi $(22,7 \%)$ yang memiliki status gizi kurang. Menurut Waryana (2010) penyebab tidak langsung status gizi yaitu ketahanan pangan di keluarga, pola pengasuhan anak, serta pelayanan kesehatan dan kesehatan lingkungan. Kondisi lingkungan adalah tersedianya air bersih, ventilasi yang memadai, lingkungan yang tidak dengan para perokok. Faktor kondisi lingkungan yang kurang baik dimungkinkan menjadi faktor penyebab gizi kurang. Berdasarkan observasi yang dilakukan, lingkungan Kelurahan Setabelan khususnya RW 5 termasuk padat hunian dan masih banyak pula rumahrumah yang lembab dengan penyediaan ventilasi yang kurang memadai. Kemudian adapula anggota keluarga terutama kaum pria, banyak yang merokok. Kondisikondisi ini dapat menyebabkan timbulnya penyakit infeksi seperti ISPA, asma, cacingan dan penyakit kulit. Hal inilah yang dapat mempengaruhi status gizi bayi.
Dari hasil penelitian juga diperoleh 18 bayi yang tidak mendapatkan MP-ASI tidak tepat, 14 bayi $(28,2 \%)$ memiliki status gizi kurang. Di Kelurahan Setabelan faktor lain yang dapat berpengaruh yaitu pemberian MP-ASI dini. Sebanyak 16 responden sudah memberikan MP-ASI pada bayi sebelum usia 6 bulan berupa susu formula dan biskuit/serelac. Susu formula yang encer dapat mengakibatkan kekurangan gizi karena asupan yang kurang pada bayi. Pemberian MP-ASI seharusnya mulai dilakukan setelah bayi berusia 6 bulan (Sulistyoningsih, 2012), namun kondisi di lahan sangat bertentangan dengan teori. Hal inilah yang dapat mempengaruhi status gizi bayi, sehingga bayi memiliki status gizi kurang.

\section{KESIMPULAN}

Berdasarkan hasil analisa dan pembahasan yang telah diuraikan pada bab sebelumnya dapat ditarik kesimpulan sebagai berikut :

1. Di wilayah Kelurahan Setabelan pemberian makanan pendamping ASI secara umum cukup baik, terlihat dari 40 responden mayoritas memberikan makanan pendamping ASI yang tepat sebesar $55,0 \%$

2. Status gizi bayi usia 6-24 bulan di wilayah Kelurahan Setabelan didominasi oleh status gizi baik yaitu mencapai $52,5 \%$

3. Kesimpulan dari hasil penelitian menunjukkan ada hubungan antara pemberian makanan pendamping ASI dengan status gizi bayi usia 6-24 bulan di wilayah Kelurahan Setabelan dengan keeratan hubungan sedang

\section{DAFTAR RUJUKAN}

Almatsier, S., 2010. Prinsip Dasar Ilmu Gizi. Jakarta: Gramedia Pustaka Utama pp. 24, 45.

Apriadji, W. H., 2007. Good Mood Food. Jakarta: Gramedia Pustaka Utama pp. 15. 
Dahlan, M. S., 2011. Statistik Untuk Kedokteran dan

Kesehatan: Deskriptif, Bivariat, dan Multivariat, Dilengkapi Aplikasi dengan Menggunakan SPSS Edisi 5. Jakarta: Salemba Medika pp. 107.

Devi, N., 2010. Nutrition and Food untuk Keluarga. Jakarta: PT Kompas Media Nusantara pp. 17$21,25$.

Dewi, R. K., 2010. Hubungan Pola Pemberian Makanan Pendamping ASI dengan Status Gizi pada Balita usia 6-12 Bulan di Desa Kaliori Kecamatan Kalibagor Kabupaten Banyumas. Jurnal Ilmiah Kebidanan, 1.

Kemenkes RI Direktorat Jenderal Bina Kesehatan Masyarakat., 2012. Pedoman Umum Pemberian Makanan Pendamping Air Susu Ibu (MP-ASI) Lokal. Jakarta : MP-ASI.

Mahaputri Ulva Lestari, G. L., Dian Pertiwi., 2014.

Hubungan Pemberian Makanan Pendamping Asi (MP-ASI) dengan Status Gizi Anak Usia 1-

3 Tahun di Kota Padang Tahun 2012. Jurnal Kesehatan Andalas, 3.

Nasar., 2011. Buku Ajar Nutrisi Pediatrik dan Penyakit Metabolik. Jakarta: Badan Penerbit IDAI pp. 33.

Notoatmodjo, S., 2010. Metodologi Penelitian Kesehatan. Jakarta: Rineka Cipta pp. 131, 139, 176.

Nurcholis. 2013. Makalah Kebutuhan Gizi Bayi dan Balita.

https://www.academia.edu/8744990/Makalah_ kebutuhan_Gizi_Bayi_dan_Balita. (27 Januari 2015)

Prabantini, D., 2010. A to Z Makanan Pendamping ASI. Yogyakarta: ANDI pp. 70
Profil Kesehatan Kota Surakarta., 2012. Jumlah Status Gizi Balita Menurut Jenis Kelamin Tahun 2012. Surakarta : Dinas Kesehatan Kota Surakarta, tabel 27

Profil Kesehatan Puskesmas Setabelan., 2014. Hasil Pengukuran Status Gizi Anak Balita di Wilayah Puskesmas Seabelan Tahun 2014. Surakarta : Puskesmas Setabelan

Riset Kesehatan Dasar., 2007. Pengukuran dan Pemeriksaan. Jakarta : Badan Penelitian Dan Pengembangan Kesehatan Departemen Kesehatan pp. 13-5

Sandjaja., 2009. Kamus Gizi. Jakarta : Kompas pp. 25.

Saryono., 2010. Metodologi Penelitian Kebidanan. Jakarta: Nuha Medika pp. 13

Sentia Novela, Debi., 2013. Anak Hidup Sehat dengan Gizi Seimbang. http://fkm.unand.ac.id/images/DEBI_SENTIA _NOVELA.pdf . (15 Januari 2015)

Soetjiningsih., 2010. Tumbuh Kembang Anak dan Remaja. Jakarta: Sagung Seto pp. 15.

Sugiyono., 2011. Statistika untuk Penelitian. Bandung: Alfabeta pp. 231

Supariasa, I. D. N., 2012. Penilaian Status Gizi. Jakarta: EGC pp. 36-7, 56-7

Waryana., 2010. Gizi Reproduksi. Yogyakarta: Pustaka Rihama pp. 46, 50

Cite this article as: Wardani, K. (2018). Hubungan Pemberian Makanan pendamping ASI Dengan Status Gizi Bayi Usia 2-24 Bulan, Jurnal Ilmiah Media Husada. 7(2), 70-75. https://doi.org/10.33475/jikmh.v7i2.22 